\title{
ANALYSIS SUPPLY CHAIN MANAGEMENT OF TOMATO BEEF AGRIBUSSINESS (Case Studies of Tani Maju Group in Junggo Hamlet, Bumiaji District, Batu)
}

\author{
Sri Ratna Triyasari ${ }^{1^{*}}$, Abdul Wahib Muhaimin ${ }^{2}$, Djoko Koestiono $^{2}$ \\ Department of Socio-Economic, Faculty of Agriculture, University of Brawijaya, Veteran street, Malang \\ 65145, Indonesia
}

Received: 28th August 2015; Revised: 8th October 2015; Accepted: 13th October 2015

\begin{abstract}
ABSTRACK
Main strength of agribusiness is the fulfillment of demand for agricultural products. However, this demand is often located in cities and industrial centers, whereas the production site of agribusiness is always far away from cities and industrial centers where the demand derives from. Indonesian farmers are lacking of competing ability, and therefore, it is hard to give better quality of supply and more punctuality of procurement. Punctuality is highly required by consumer and therefore, this research attempts to discuss punctuality. The objective of research is to analyze the performance of tomato beef supply chain management and the long-term relationship among the agencies of tomato beef supply chain management. To achieve this objective, research uses analysis methods of SCOR AHP and descriptive statistic. Result of research indicates that the performance of tomato beef supply chain management may be classified already as the good one but it can still be improved by establishing the main priority or the best solution alternative for supply chain management, which respectively is the making of long-term business contract. Therefore, long-term relationship among the agencies of tomato beef supply chain management will be stronger.
\end{abstract}

Keywords: supply chain management; tomato beef; performance; long-term relationship

\section{Introduction}

The main strength of agribusiness is in fulfilling the demand for agricultural products. However, this demand is often found in cities and industrial centers where the consumption begins. In other hand, agribusiness is always managed within production centers that stand over agriculture lands (Ganesan dan Shankar, 1994). For instance, tomato beef is planted on production centers in Batu City while the consumers of tomato beef are mostly the occupant of the downtown of cities or the consumption centers. How this product can be carried over from production centers to consumption centers while good quality is still kept? The answer to this question is significantly influential because the production of a certain product always involves a lot of stages that each of them creates certain added value. Besides, the

*Correspondence author.

E-mail: ratnatriyasari@gmail.com concept of just-in-time is quite familiar among consumers or even desirable by them (Kipdiyah et.al., 2013).

Farmers find difficulty to meet this demand because of lacking of competing ability. Their limited access to market, inadequate information about market, and less experience in dealing with big market or large company, are characterizing such farmers. Therefore, to keep the smooth flow of their production yield, farmers need other agencies to bring their farming product to consumers. Main impediments in supply chain include planning, socialization and delivery (Richardus et.al., 2002).

These impediments have challenged agencies in supply chain structure. By allowing these unresolved, it can deteriorate supply chain, cause the loss, and impede the achievement of collective goal, which is consumer satisfaction (Pujawan et.al., 2010). This background above precedes the objective of research which is to analyze the performance of tomato beef supply chain management and the long-term relationship among the agencies of tomato beef supply chain 
management. Analytical method includes Analytical Hierarchy Process (AHP) and descriptive statistic.

\section{Method of Research}

Research site is purposively selected, respectively in Junggo Hamlet, Bumiaji District, Batu City. The population of research includes partner farmers, input provider agencies, intermediate merchants, and modern retail companies. The selected sample is obtained by sorting this population through census method by which resulting in 30 partner farmers, 1 input provider agency (Rijk Zwaan), 1 fertilizer provider company (PT. Tirta Excelindo), and 1 rain shelter plastic provider company (PT. Condido Agro). There are 3 intermediate merchants involved. Respondent from modern retail company is acquired by the use nonprobability sampling method with judgmental sampling technique. There are 6 company respondents, respectively Hero Sidoarjo, Hero Surabaya, Papaya, Hotel Tugu Malang, Restoran Dragon Phoenix Malang, and Katering Kaliurang Malang. Final consumer to assess their satisfaction on tomato beef is determined using non-probability sampling method with convenience sampling technique. Total respondent of consumer is counted for 30 persons.

Method to collect primary data is structured interview to obtain information about the supply chain management of tomato beef agribusiness, the respondent characteristic, the sale and buy prices of tomato beef, and the base activity of supply chain management. Secondary data are obtained from the provider of tomato beef seed who will give information about tomato beef cultivation SOP (standard operating procedure).

Data analysis method to answer the first research objective (to analyze the performance of tomato beef supply chain management) is Supply Chain Operations Reference (SCOR). This method will describe the base activity of supply chain management which includes planning, sourcing, producing, delivering and returning. After analyzing these base activities of supply chain management, SCOR-Card is the made and given to each agency of tomato beef supply chain management. SCOR-Card is compared to consumer satisfaction rate that previously examined to answer the question whether the performance of each agency has met consumer satisfaction. In this stage, the next analysis will provide the best solution alternative to establish the favorable supply chain management of tomato beef agribusiness, and the analytical instrument is Analytical Hierarchy Process (AHP). Result of AHP analysis is the variable that has the highest priority value and that will influence the system of supply chain management of tomato beef agribusiness.

Data analysis method for second research objective (to analyze the long-term relationship among the agencies of tomato beef supply chain management) involves two steps. First step is to determine the variables of long-term relationship that influence supply chain management. Five variables are observed, respectively satisfaction, trust, communication, dependence and commitment (Nuryati et.al., 2012). The analysis instrument is descriptive statistic with Liket Scale. A program that specializes to compute and record the data, PSPP, is used to facilitate the analysis of these variables. Result of this analysis is the value that determines the category of longterm relationship among the agencies of supply chain management.

Second step is to analyze the correlation between the performance of supply chain management and the long-term relationship of tomato beef supply chain management. Correlation test of Kendall's Tau is used to measure the relationship of these two variables based on the rank. This test is also useful to understand whether the relation is close or open, the direction of relation is clear or uncertain, and the relation is meaningful or not (Setiawan et.al., 2011).

\section{Result and Discussion}

\subsection{Analysis with Supply Chain Operations Reference (SCOR)}

1. Planning Process (Plan)

Planning may involve assessing the distribution demand, planning and controlling the stock, planning the production, planning the material, planning the capacity, and making adjustment of supply chain planning with financial plan. These planning processes are facilitating other activities.

The activity of planning among partner farmers in their supply chain management is associated with planning for production estimation. This estimation is based on previous harvest and current climate. This planning is also 
benefiting the intermediate merchants for informing them about supply certainty, especially to meet the order from modern retail company. By this estimation, the inaccurate stocking of tomato beef can be anticipated by using not too high slack.

Production process needs inputs. Partner farmers also plan certain raw materials as the inputs to their cultivation. Partner farmers may cooperate with input provider agencies. The effect of this cooperation is that input demand has been fixed at certain number. Therefore, partner farmers only plan input demand based on the fixed amount.

\section{Sourcing Process (Source)}

Sourcing process is to procure goods or services to meet the demand. The activity involves scheduling the delivery to intermediate merchants, accepting the goods, and giving payment for the goods. Partner farmers also conduct sourcing-related activity such as making stock of tomato beef seed, frampion fertilizer and rain shelter plastic. The sourcing also involves other inputs but the author only confines research to these three inputs.

Tomato beef seed is accepted by partner farmers a day before planting. Partner farmers give signature to the receipt. If partner farmers cannot settle the payment, intermediate merchants can finalize the settlement. Therefore, partner farmers owe to intermediate merchants.

The acceptance of rain shelter plastic and fertilizer is also given through the hand of partner farmers but the settlement of payment is still conducted by intermediate merchants. It may be previously set under the agreement between the partnered actors of supply chain management. Especially, it may be helpful for partner farmers in looking for capita. It allows partner farmers to be more focused upon their production.

Intermediate merchants give loan to partner farmers to source the production inputs. UV Plastic at rain shelter size is priced at Rp. 38,000.- per $\mathrm{kg}$ whereas the seed is set at Rp. 2,500.- per stem for variety Doufu. All these prices are prevailed in early planting period and must be paid when partner farmers supply tomato beef to intermediate merchants. Partner farmers incur the rest of finance during the cultivation until the end of production.

The payment by intermediate merchants for the commodity delivered by partner farmers is made based on the value of commodity sold by intermediate merchants in every week after deducing the loan of rain shelter plastic and seed. The weekly bill stated on the loan card held by intermediate merchants will be settled on the next week day, particularly every Friday.

Partner farmers do sourcing of workers from their own household. It means that the household of partner farmers are the cultivator of planting. Partner farmers only need additional workers during harvest for picking and carrying the basket of tomato beef to the transport vehicle. The picker is usually woman who works for Rp. 30,000.- / one time harvest. Payment is directly given by partner farmers to this additional worker.

\section{Producing Process (Make)}

Producing process is to transform raw materials/production inputs into the product expected by consumers. Tomato beef producing process is based on make-to-stock or aimed to meet the target of fulfilling consumer demand. The activity in producing process involves scheduling the production, undergoing the production activity, and performing the maintenance.

Input provider agencies also have their own producing process, respectively by providing tomato beef seed and fertilizer. The provider of rain shelter plastic is not conducting production of their own but only orders the stock from the company that manufactures rain shelter plastic and then resells this plastic to partner farmers. The producing process of partner farmers is described as follows:

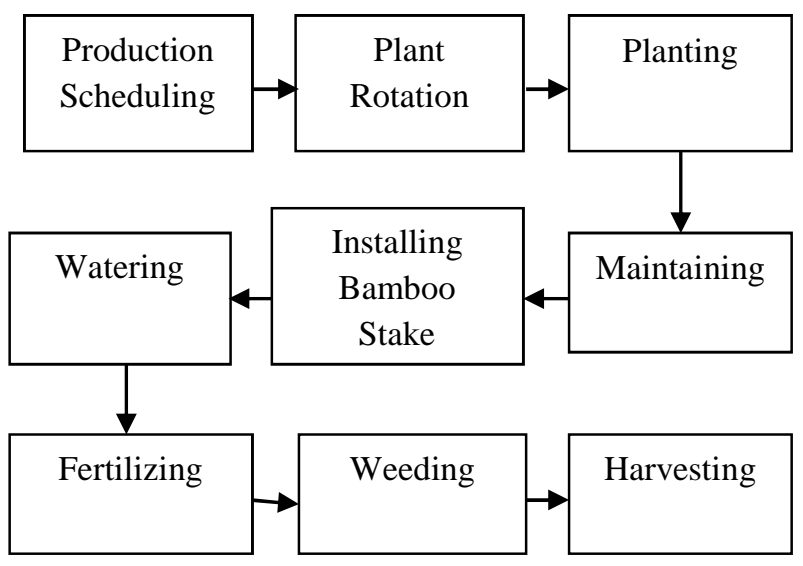

Figure 1. Producing Process of Tomato Beef by Partner Farmers

The process begins with production scheduling. It determines plant rotation or plant patterning. This rotation or patterning is aimed to break the life cycle of pest and disease at certain region or certain land. Plant rotation starts with 
cabbage on January-March, and makes a rotation with tomato on April-June. On July-September, the land is filled with peanut, and finally, cultivated for pepper on October-December. However, timing and commodity used for plant patterning may vary across partner farmers, or even change depending on planting season and climate at cultivation area. Other influential factors may include the precision of selected location, the arrangement of patterning, the arrangement of planting system, the selection of seed variety and the timing of planting (Prabaningrum et.al., 2014).

Next activity is tomato beef planting. Partner farmers plant the seed at afternoon around $15.00-16.00 \mathrm{pm}$. This timing is selected to avoid plant death due to high temperature. Tomato beef seed is relieved from the seedling tray or bamboo tube. The seed is then planted to the prepared planting hole.

Maintaining activity is undergone during cultivation when tomato beef reaches 3-4 weeks after planting. Bamboo stake is installed to support the plant to stand tall. The stem of tomato is tied onto bamboo stake with rope. The binding is done every week to adjust with the development of plant height. Subsequently, branching is conducted against the plant at 4 weeks after planting to produce main branch. In every tree, 2 main branches are left. In every week, every new seedling is removed, and in each main branch, 3-5 fruit bunches are allowed.

Watering and fertilizing are done since early planting until 2 weeks after planting. Water may be given daily. After 2 weeks after planting, water is only treated on demand. However, too few waters can slow the growth. Root may become less and shallow that the bigger plant is hard to absorb nutrients. Too many waters are also bad because it may carry fertilizer too deep into the ground, which causes difficulty for tomato beef to maximize the use of fertilizer.

Next activity is weeding at 4 weeks after planting. Follow-up weeding is given at 8 and 12 weeks after planting. Land must be cleaned from the grass species of "babadotan" or "wedusan" (Ageratum conyzoides L.) which become the host for the pest of kutu kebul (Bemisia tabaci). Treatment may include cutting the branch at 4 weeks after planting in order to produce main branch. Only 2 main branches are left in every tree. In every week, every new seedling is removed, and in each main branch, only 3-5 fruit bunches are allowed.
The final producing process is harvesting. Tomato beef is harvested at 80 days after planting. For distant delivery, tomato beef is harvested at $70 \%$ maturity level, and for short journey, full maturity is considered. For short transportation, tomato beef is only packed into bamboo basket, whereas for distant delivery, it uses wooden case at the capacity of $5-10 \mathrm{~kg}$.

After delivery, intermediate merchants will do post-harvest activity after tomato beef enters the warehouse. Tomato beef is then cleaned manually by rubbing the skin with clean half-wet cloth. After cleaning, each tomato beef is weighted and sorted based on weight, size and maturity level.

The sorting helps separating good category of tomato beef, whereas the bad product enters the grades assigned as Grade A to D. Bad fruit may be caused by mechanical damage, pest and disease attack, decay, and abnormal shape, size and maturity level. Such classification is called as Grade Krill. The objective of sorting is to obtain the uniformity of weight, size, maturity level, texture, color and other quality aspects.

\section{4. $\quad$ Delivering Process (Deliver)}

Delivering process is a process of making journey to meet the demand for tomato beef. It may happen from partner farmers to intermediate merchants or from intermediate merchants to every modern retail company. This process involves activities such as accepting the orders from other partners, preparing the transportation, and sending tomato beef to the warehouse owned by intermediate merchants.

This delivery is made directly after harvest, or usually at noon. Warehouse is often nearby the cultivation land of partner farmers, and it is planned in such way that it will reduce the damage level of tomato beef during transportation if the warehouse is located far away. Transporting tomato beef from cultivation land to warehouse is using pickup vehicle owned by partner farmers. Some partner farmers may not have such vehicle but other partner farmers may lend without cost or with very cheap rent.

The delivered tomato beef is arranged into big plastic basket with spaces or air cavities at the capacity of 20-30 kg. After entering warehouse, intermediate merchants will do post-harvest activity as previously explained.

\section{Returning Process (Return)}

Returning process is a process to accept the return of products due to damage, defect, 
unpunctuality, and other causes. The activity in the returning process may involve accepting the returned product, managing the administration of returning, verifying the returned product, and exchanging the product.

So far, partner farmers do not experience the return of tomato beef from intermediate merchants. The partnership agreement made by both has stated that intermediate merchants are required to by tomato beef produced by partner farmers at all quality levels, and there is no arrangement for returning tomato beef to partner farmers in the case of unexpected condition.

However, the returning can also happen once. The product is returned because the package at certain quality is mixed with other quality level. After re-delivery, intermediate merchants re-sort the product to ensure the uniformity of quality level of tomato beef.

The returning is rarely happening because the demand of tomato beef is always high, and therefore, modern retail company chooses to sell all grades of tomato beef but by still considering esthetic and specific qualities of tomato beef itself. Catering and restaurant companies are often the buyer with great order for tomato beef because tomato beef can be processed with another material.

\subsection{The Compose of SCOR-card}

SCOR-Card explains the performance value of each matrix indicator. The criteria used to measure the performance of supply chain include reliability, responsiveness, flexibility, cost, and management.

Input provider agencies in supply chain management of tomato beef agribusiness include the provider of fertilizer and the provider of rain shelter plastic. The compose of SCOR-Card consists of several items such as: the performance of supply chain actors in meeting the order; the precision of quantity and quality; and the precision of punctuality; and the smooth information across supply chain actors. The performance of all input provider agencies is ranked at 73 and classified into good category. It means that the performance of input provider agencies is good with value of 27 .The supply chain management of tomato beef agribusiness must be improved to have better performance. The rate of gap requirements must be reduced or even be eliminated to facilitate the improvement of performance.

SCOR-Card composed for partner farmers is designed to be used by 30 partner farmers. The data for the reference are the production result of all partner farmers in one harvest period. From this production result, it can be known for the precision of quantity, quality and delivery from partner farmers to other supply chain actors, especially intermediate merchants. It is also understood that average performance rate of al partner farmers is 81, and it means good category. This rate is quite good although it is one level below excellent category. The performance can be improved to get better rate or to make it classified for excellent category. The performance of partner farmers can still be improved until the rate of 19 .

SCOR-Card for intermediate merchants is composed based on the performance to meet the order with the precision of timing, quantity and quality. The obtained rate is 69 which enters average category. It means that intermediate merchants have average performance, and this performance shall be improved to the rate of 31 . The compose of SCOR-Card for modern retail company is using the data of tomato beef quantity sold to consumers, sale timing, promotion of tomato beef, and company resilience and competence to adapt with market change to keep intact the competing ability of supply chain. It is known that the performance of all modern retail companies is 67 and classified into average category.

\subsection{Consumer Satisfaction to Tomato Beef}

In general, main goal of a supply chain is to fulfill consumer satisfaction (Marimin dan Maghfiroh, 2010). Consumer satisfaction rate to the attributes of tomato beef is varying. The attributes that give the highest satisfaction rate at point 3 and thus are classified into satisfying category are aroma, color and freshness. Attributes in average category are texture, price and size. The attribute with the lowest satisfaction rate is only one which enters notsatisfying category, which is availability. Consumer dissatisfaction against the availability is consistent to field observation that shows that the quantity and the quality of supply remain uncertain.

It means that the performance of each agency in performing the supply chain management of tomato beef agribusiness is not maximum and not yet successful in meeting consumer satisfaction. To achieve consumer satisfaction, the agencies in supply chain management must cooperate to improve their activities. Therefore, next action is to select the 
best solution alternative for supply chain management of tomato beef agribusiness.

\subsection{The Best Solution Alternative for Supply Chain Management of Tomato Beef Agribusiness}

The output of data processing to select the best solution alternative for supply chain management of tomato beef agribusiness is explained as follows. Consistency will be acceptable if CR value is not more than 0.1 (CR $\leq 10 \%)$. The result of Expert Choice output is $\mathrm{CR}=0.05$, which means that this value is similar to $10 \%(0.05=0.1)$. All valuations are consistent and the result of weighting is acceptable based on the consistency of filling.

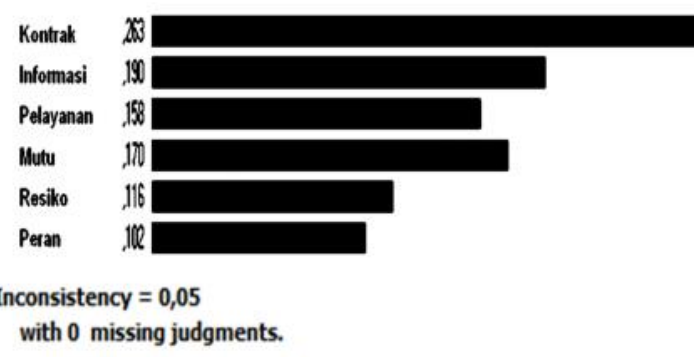

Figure 2. Result of AHP Processing to Select The Best Solution Alternative

Global solution alternative is determined by measuring the performance of tomato beef supply chain management. Result of AHP indicates that long-term business contract is the main priority. This main priority is weighted to 0.263 . Second priority is information openness that weighted at 0.190 . Third priority is the increase of favorable quality warrant that weights for 0.170 . Fourth priority is good service weighted to 0.158 . Fifth priority is proper distribution of risk, and it weights for 0.116 . The final priority is the involvement of government that weights for 0.102 .

\subsection{Long-Term Relationship Variables}

Satisfaction, trust, communication, dependence, and commitment are variables which their influences on long-term relationship are sequentially arranged. Initially, satisfaction to performance and service given will establish trust to share matters during the cooperation. Smooth communication may produce dependence by which each partner can signalize the commitment to keep and to sustain long-term relationship (Astuti et.al., 2012).

Long-term relationship is very necessary for supply chain management, especially for the actors who build partnership. This research attempts to analyze the influence of five variables of long-term relationship on tomato beef supply chain management. These variables are explained in the following graphic:

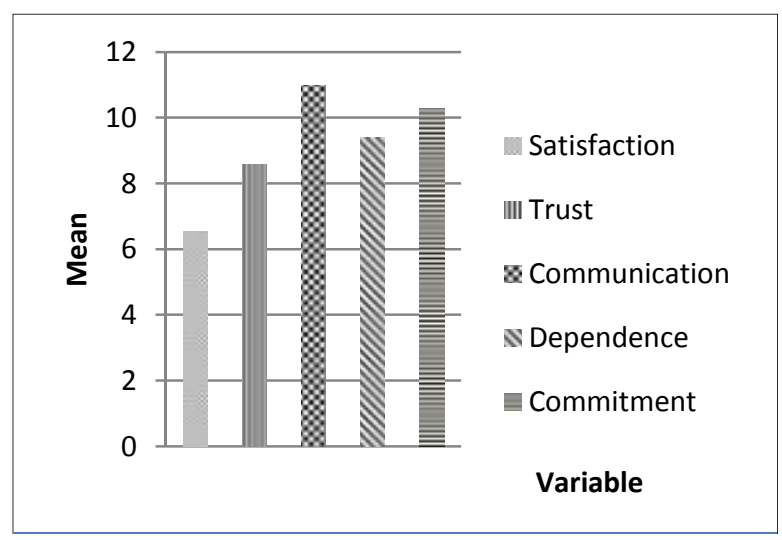

Figure 3. The Influence Rate of Five Variables of Long-Term Relationship on Supply Chain Management of Tomato Beef Agribusiness

Figure 3 indicates that communication has the most dominant effect among long-term relationship variables on tomato beef supply chain. The highest influence rate, thus, is contributed by communication, with average rate of 10.39 or $23.96 \%$. Indeed, communication is needed for long-term relationship because it represents a method to deliver message information between the actors of tomato beef supply chain management. Communication also facilitates the activity of supply chain management across the related actors.

The next highest influence rate is shown by commitment with average rate of 10.29 or $22.45 \%$. The actors of supply chain have considered the commitment as important among them. Commitment represents an agreement among supply chain actors to manage their partnership properly and to execute the cooperation based on predetermined rules. Commitment also reflects a belief shown by a certain party that building a relationship with other party is important and influential to the optimum benefit of both parties in cooperation. Many actors of tomato beef supply chain assert that commitment is a part of good intention to keep intact the existing cooperation.

The next highest rate is shown by dependence with average rate of 9.39 or $20.48 \%$. Dependence among respondents in tomato beef supply chain is considered as high. Respondents feel that their dependence on inputs from other agencies is often great. This is quite apparent due 
to some reasons. Among other, raw materials are always needed for production. Some agencies have excess capacity to meet the goal of their partners. There is a necessity to obtain external resource and to manage market consolidation. The entry barrier against market access can also induce dependency among members and partners in supply chain (Verdiar et.al., 2014).

Variables of long-term relationship with the lowest influence rate on tomato beef supply chain management are trust and satisfaction. Trust has average rate of only 8.58 or $18.71 \%$. It is low because there is a dispute and the problem solving seems hard. Problems must be removed because this removal will help to build the trust as the important part in developing long-term relationship in supply chain management of tomato beef agribusiness.

Satisfaction also has low influence rate as proved by average rate of 6.54 or $14.28 \%$. The actors of supply chain management of tomato beef agribusiness are not quite satisfied because some of them do not find good performance from others. Satisfaction shall not be sensed unilaterally, but all supply chain actors must satisfy with performance of other agencies.

Supply chain management, essentially, covers wider sense of work and responsibility. Thus, supply chain management involves many parties inside or outside a certain agency, and also deals with various activities. However, what is said by theory of supply chain management is always different from reality and field condition.

Result of analysis indicates that the influence of long-term relationship variables is not ordered sequentially. On field observation, supply chain management can be uncertain. The uncertainty is a main source of difficulty in supply chain management (Anatan et.al., 2008). This uncertainty can deteriorate self-confidence to execute the plan. The uncertainty in supply chain management emanates from three causes, respectively: the uncertainty of order when the supplier feels uncertain to delivery lead time, raw material price or production component; the uncertainty of quality and quantity of the delivered material; and the uncertainty of internal (Anatan et.al., 2008). As shown in field condition, tomato beef production is influenced by factors internal and external to cultivation, and these factors may bring up the uncertainty of quality and quantity of tomato beef.

The tardiness in supplying raw materials can produce congestion in production process because without raw materials, production process may not run. An optimum supply chain is where materials and components are accepted punctually and ready for lean manufacturing such that the proper products are in the right place, at the right time and with the lowest price (Bernard et.al., 2011).

\subsection{The Correlation Between The Long- Term Relationship Variables on Supply Chain Management and The Performance of Supply Chain Management of Tomato Beef Agribusiness}

It is important to analyze the connection between the long-term relationship variables on supply chain management and the performance of suppliers, such as partner farmers and other partners, in supply chain management of tomato beef agribusiness. The result of analysis can be used to evaluate the performance of certain agencies compared to another. The result also gives a reference to make suggestion for the improvement of performance of the supplies. The correlation between long-term relationship variables and the performance of supplier in supply chain management of tomato beef agribusiness is understood using Correlation Test of Kendall's Tau.

Correlation Test of Kendall's Tau is measuring the degree of closeness of the connection between a variable and another. In this case, the correlation between long-term variables and supplier performance is examined. Kendall's Tau method begins with making the rank list based on initial observation. The obtained rank is then adjusted with the existing pairs. Correlation rate ranges from -1 to 1 . If the rate approaches to 1 or -1 , it means that the correlation of two variables is stronger. If the rate stays near 0 , the correlation of two variables becomes weaker. Positive rate is for parallel correlation, whereas negative rate is for inverse correlation.

Result of analysis also shows that there is a positive correlation among long-term relationship variables, including satisfaction, trust, communication, dependence and commitment. There is also a significant correlation between long-term relationship variables and supplier performance in supply chain management of tomato beef agribusiness. Satisfaction is rated as 0.357 , whereas trust is rated for 0.547 . Communication is given rate of 0.761 , while dependence is stood for 0.856. The rate of commitment is 0.661 . All these results are nearby 
1, meaning that all variables have strong correlation with supplier performance. The variable with the strongest correlation is dependence.

Positive correlation means that dependence is positively and significantly correlated to the performance of each agency in supply chain management of tomato beef. The higher dependence among the agencies is the better long-term relationship across these agencies.

\section{Conlusion}

By taking account the result of research, it can be concluded that:

The performance of supply chain management of tomato beef agribusiness is classified into good category. It means that there is good coordination and cooperation between agencies starting from the sourcing of production inputs until the delivery of tomato beef to consumers. This performance can be improved still by applying the best solution alternative to establish better supply chain management of tomato beef agribusiness. This best solution alternative involves some priorities. First priority is long-term business contract across agencies. Second priority is information openness. Third priority is giving warranty for better quality. Fourth priority is good service. Fifth priority is proper risk distribution. Sixth priority is the involvement of government.

The long-term relationship variable with the greatest influence on supply chain actors is communication with average rate of 10.98 , and this is potential for long-term relationship. Second variable is commitment with average rate of 10.29 and also potential for long-term relationship. Third variable is dependence with average rate of 9.39 and it is also potential for long-term relationship. Trust as fourth variable is rated averagely only at 8.58 and also potential for long-term relationship. The variable with the lowest influence rate is satisfaction with average rate of 6.54 and definitely with less potential to develop long-term relationship. Based on the correlation between long-term relationship variables and supplier performance, it is shown that dependence is the variable with strong correlation with supplier performance at rate of 0.856 .

\section{References}

[1]. Anatan, L. dan Ellitan, L. (2008). Supply Chain Management Teori dan Aplikasi (p. 57). Bandung: CV. Alfabeta.

[2]. Astuti, D. R., Koernawati, T., Hardani, M. (2012). Identifikasi Hubungan Jangka Panjang Dan Analisis Keberadaan Rantai Pasok Di Agroindustri Kerupuk Singkong Dalam Rangka Mewujudkan Penganekaragaman Pangan. AGRISE Volume XII No. 1. Malang.

[3]. Bernard, S. F. dan Sugiarto, Y. (2011). Analisis Pengaruh Faktor-Faktor Kualitas Hubungan Terhadap Kinerja Rantai Pasok. Jurnal E-prints Undip. Vol. 15, No. 2, h. 21-31.

[4]. Ganesan, S. (1994). Determinants of Long Term Orientation in Buyer-Seller Relationship. Jurnal Pemasaran. Vol. 58, April 1994, 1-19.

[5]. Kipdiyah, S., Hubies, M., dan Budi, S. (2013). Strategi Rantai Pasok Sayuran Organik Berbasis Petani di Kecamatan Pangalengan, Kabupaten Bandung. Jurnal Manajemen IKM. Institut Pertanian Bogor, Vol. 6 No. 2.

[6]. Laksminiwati, P., Moeksan, T. K., dan Adiyoga, W. (2014). Panduan Praktis Budidaya Tomat Berdasarkan Konsepsi Pengendalian Hama Terpadu (PHT). Jakarta: Penebar Swadaya.

[7]. Marimin dan Maghfiroh. (2010). Aplikasi Teknik Pengambilan Keputusan dalam Manajemen Rantai Pasok. Bogor: IPB Press.

[8]. Nuryati Dan Heri, B. (2012). Analisis Pengaruh Komitmen untuk Mencapai Hubungan Jangka Panjang. Jurnal Sains Pemasaran Indonesia. Volume II. Nomor 1. P. 85-92.

[9]. Pujawan, N. dan Mahendrawathi, E. R. (2010). Supply Chain Management. Edisi Kedua. Surabaya: Guna Widya.

[10]. Richardus, E. dan Djokopranoto. (2002). Konsep Manajemen Supply Chain. Cara Baru Memandang Mata Rantai Penyediaan Barang. Jakarta: PT Gramedia widiasaranana Indonesia. 
[11]. Setiawan, A., Marimin, Y., dan Arkenan. (2011). Studi Peningkatan Kinerja Manajemen Rantai Pasok Sayuran Dataran Tinggi di Jawa Barat. Jurnal Agritech. Institut Pertanian Bogor,. Vol. 31, No. 1.

[12]. Verdiar, R., Praditya, S., dan Yolanda, M. (2014). Pengaruh Ketergantungan dan Keoercayaan pada Pemasok terhadap Kinerja Keuangan Melalui Integrasi dengan Pemasok pada Perusahaan Manufaktur di PIK, Pulogadung. E-Journal Manajemen Fakultas Ekonomi. Universitas Trisakti. Jakarta. Volume. 1 Nomor. 1. Hal 76-92. 